\title{
EXPERIMETNAL INVESTIGATION ON THE LOAD-DEFLECION BEHAVIOUR OF CRACKED CONCRETE BEAM BY PARTIAL REPLACEMENT OF COARSE AGGREGATE WITH CINDER
}

\author{
K Sindhu ${ }^{1}$, P Poornima ${ }^{2}$ \\ ${ }^{l}$ PG Student, Department of Structural Engineering, Sree Rama Engineering College, Rami Reddy Nagar, Tirupati, \\ Andhra Pradesh, India, \\ ksindhu230@gmail.com \\ ${ }^{2}$ Assistant Professor, Department of Structural Engineering, Shree Rama Educational Society Group of Institution, \\ Karkambadi, Tirupati, India, \\ poornimapoori.123@gmail.com
}

\begin{abstract}
Rapid industrial growth, Environmental pollution, Scarcity of natural resources, Economic design of structural elements, Adoptability and suitability of new materials, Disposal problems, Cost effective projects, Usage of many industrial wastes for use in cement concrete applications have initiated the present investigation. The measure of soot squanders is entirely expansive in India for use as a total in cement. Ash is delivered amid blazing of coal in numerous businesses. It is the material sintered at high temperatures. There are no hurtful chemicals in soot. Squashed ash total is a material particularly proposed for the building built in hot atmospheres. The targets of this study are to show the consequences of test study and investigation on the conduct and the quality of typical quality strengthened solid pillars (NSC) and fortified solid bars with ash totals and connects their outcomes. Trial blends were made to accomplish a legitimate blend for the solid of M40 evaluation with appropriate workability to cast the bars. With the right blend extent accomplished, pillars were thrown, measurements of each being $2800 \mathrm{~mm} \times 100 \mathrm{~mm} \times 145 \mathrm{~mm}$. The support of the shafts differed from $0.84 \%, 1.31 \%$ and $1.88 \%$. The bars were cured for 28 days. Following 28 days, all the bars were tried for flexure under two point stacking in a stacking casing of 50tonnes limit. The heap was connected by method for a $100 \mathrm{kN}$ water driven jack, through a steel I-area, bolstered on two steel rollers. The result obtained was then plotted as graphs. The experimental results are compared with IS 456:2000 provisions. The analytical work involved the calculation of deflections of test beams using the methods currently available in the literature. In addition, the design provisions contained in the American Concrete Institute Building Code ACI 318-2010, British Code BS 8110 and Euro Code EN 1992 are used to calculate the strength of all the beams.
\end{abstract}

Keywords: Cinder, Coarse Aggregate, Compressive Strength, Deflection, Ultimate Loads, Working Loads. ****.

\section{INTRODUCTION}

he development business has been one of the top most divisions developing step by step with time. The building materials are obtained in huge amounts and the more seasoned structures are being destroyed to ground zero.

The interest for building materials has been constantly ascending with the expanding requirement for lodging both in rustic and urban ranges. The development business depends vigorously on traditional materials, for example, bond, rock and sand for the creation of cement. The high and expanding expense of these materials with the expanding requirement for lodging both in rustic and urban ranges.

There emerges the requirement for designing thought of the utilization of less expensive and locally accessible materials to address craved issue, upgrade self-productivity, and lead to a general diminishment in development cost for feasible advancement. It has, along these lines; get to be important to thoroughly consider this issue truly and to give some practical answer for make the option materials accessible to take care of the lodging issue. In the beginning of the force era industry, coal burning items (CCPs) were thought to be a waste material. The properties of these materials were not concentrated on or assessed genuinely and about the majority of the coal ignition items were area filled. Over the span of time, the Cementitious and Pozzolanic properties of fly ash were perceived and concentrated on by a few people and organizations. The items were tried to comprehend their physical properties, substance properties and appropriateness as a development material. Amid the most recent couple of decades these "waste" materials have seen a change to the status of "by-items" and all the more as of late "items" that are looked for development and different applications. Amid the previous quite a few years, era of power through different coal burning procedures has developed to oblige expanded populace and related modern and business improvement in the United States and different parts of the world. These coal ignition forms abandon deposits that are alluded to as CCPs. The underlying CCPs 
were called soot and were framed from smoldering knot coal on meshes in stoker heaters. These ashes were now and then utilized as street rock and now and again as a lightweight total in assembling brick work "soot" squares. Soot is a pyroclastic, uncemented material and are extrusive volcanic rocks. They are like pumice, having bubble-like pits, called vesicles measuring at the very least 2.0 millimeters in no less than one measurement. It has obvious particular gravity somewhere around 1.0 and 2.0. Regular ashes are red or dark in shading. Contain various gas bubbles "solidified" into spot as magma blasted into the air and afterward cooled rapidly. The measure of ash waste is entirely substantial in India for use as a total in cement. Soot is created amid the blazing of coal in numerous commercial ventures. It is material sintered at high temperatures. There are no unsafe chemicals in ash. Smashed ash total is a material particularly proposed for the structures built in hot atmospheres. This Chapter displays the foundation to the requirements for the improvement of cement with supplanted totals and the utilization of soot as total in cement. The accessible distributed writing on soot total cement is additionally quickly inspected.

\section{OBJECTIVE OF THE STUDY}

The present investigation can be extended to beams with many more percentages of replacement of coarse aggregates with cinder. An extensive research work has to be carried out to further study the effects of variation in tensile reinforcement with a wide range of percentage of tensile reinforcement. Investigation can also be extended to study the behaviour of doubly reinforced beams with coarse aggregates partially replaced by cinder. There is a scope for improving the codal provisions for the deflection determination of beams since; most of the codes do not predict the deflections of the beams with a reasonable accuracy. Extensive research has to be carried out on various higher concrete grades.

\section{EXPERIMENTAL PROGRAMME}

\subsection{Cement}

Ordinary Portland cement conforming to the specifications of IS: 12269-1987 was used. The cement was Ultra tech -53 Grade OPC. The chemical compositions of cement are presented in

Table: 1 Properties of Cement

\begin{tabular}{|l|l|l|}
\hline S.NO & PROPERTY & VALUES \\
\hline 1 & Specific Gravity & 3.15 \\
\hline 2 & Normal Consistency & $32 \%$ \\
\hline 3 & Setting Time & \\
& $\begin{array}{l}\text { a) Initial Setting time } \\
\text { b) Final setting time }\end{array}$ & $\begin{array}{l}40 \text { minutes } \\
6 \text { hours }\end{array}$ \\
\hline
\end{tabular}

\subsection{Fine Aggregate (FA)}

For the casting, locally available river-sand, free from silt and organic matters was procured and used. The particle size of fine aggregate used in this study was such a way that it passed through $4.75 \mathrm{~mm}$ sieve conforming to zone II of IS: 383-1970. The specific gravity of FA used was 2 .

\subsection{Coarse Aggregate (CA)}

Coarse aggregate used for the experiments was locally available crushed granite aggregate passing through $12.5 \mathrm{~mm}$ and retaining on $4.75 \mathrm{~mm}$ for all of the mixes. The aggregates used were conforming to IS: 383-1970. The specific gravity of CA used was2.74. And along with natural aggregates, Cinders were used, which were crushed down to pass through $20 \mathrm{~mm} \&$ retain on $4.75 \mathrm{~mm}$ sieves. The specific gravity of cinder used was 2.24 .

\subsection{Water}

Potable water free from injurious salts was used for both mixing and curing.

\subsection{The Mix Proportion of Normal Strength Concrete (NSC)}

The final mix proportions for M40 grade normal strength concrete is shown in Table 2:

Table 2: Mix Proportions for M40

\begin{tabular}{|l|l|}
\hline Cement & $492.9 \mathrm{~kg} / \mathrm{m}^{3}$ \\
\hline Coarse aggregate & $1099.12 \mathrm{~kg} / \mathrm{m}^{3}$ \\
\hline Fine aggregate & $673.65 \mathrm{~kg} / \mathrm{m}^{3}$ \\
\hline Water & $197.16 \mathrm{lit} / \mathrm{m}^{3}$ \\
\hline
\end{tabular}

The final mix proportions for various replacements of coarse aggregate are tabulated below in Table 3:

Table 3: Final Normal concrete mix proportions (M40)

\begin{tabular}{|l|l|l|l|}
\hline MIX No. & $\begin{array}{l}\text { CINDER } \\
\text { REPLACEMENT } \\
\%\end{array}$ & $\begin{array}{l}\text { NCA } \\
\text { Kgs }\end{array}$ & $\begin{array}{l}\text { CINDER } \\
\text { kgs }\end{array}$ \\
\hline NSC MIX 1 & 0 & 1098.04 & - \\
\hline NSC MIX 2 & 30 & 768.63 & 329.41 \\
\hline NSC MIX 3 & 50 & 549.02 & 549.02 \\
\hline NSC MIX 4 & 75 & 274.51 & 823.53 \\
\hline
\end{tabular}

\subsection{Test Specimens}

Accordingly, dimensions of the beam elements are explained below:

Overall Length $=2800 \mathrm{~mm}$,

Effective Length $=2400 \mathrm{~mm}$

Overall Depth $=145 \mathrm{~mm}$,

Breadth $=100 \mathrm{~mm}$,

Clear cover $=20 \mathrm{~mm}$, An "Effective Length by Overall Depth" ratio close to 15 considered.

IS 456:2000 guidelines regarding the minimum and the maximum reinforcement were used to obtain a practical range of the steel ratios which is permissible also. The maximum reinforcement in a beam according to the IS codes is to be kept within $4 \%$ of the cross sectional area. The percentage of reinforcements adopted were $0.84 \%, 1.31 \%$ \& $1.88 \%$ of the cross sectional area of the beam. Table-4below shows the details of the reinforcement used for the beams. 
Table 4: Reinforcement calculations

\begin{tabular}{|l|l|l|l|}
\hline $\begin{array}{l}\text { Beam } \\
\text { no. }\end{array}$ & Reinforcement & $\begin{array}{l}\left.\mathrm{A}_{\text {st }}\right) \text { prov } \\
\mathrm{mm}^{2}\end{array}$ & $\begin{array}{l}\left.\mathrm{A}_{\text {st }}\right) \text { prov } \\
(\%)\end{array}$ \\
\hline 1 & $8 \mathrm{~mm}$ dia-2 nos & 100.53 & 0.84 \\
\hline 2 & $10 \mathrm{~mm}$ dia-2 nos & 157.08 & 1.31 \\
\hline 3 & $12 \mathrm{~mm}$ dia-2 nos & 226.19 & 1.88 \\
\hline
\end{tabular}

As the main aim of the present study is to investigate the flexural behaviour of RC beam elements, there should not be any other possibilities of failure occurrence rather than flexural failure. Consequently, beams should be designed for shear such a way that even under the ultimate moment carrying capacity shear failure doesn't happen.Percentages of reinforcement are carried out and the results are tabulated in the Table 5:

Table 5: Selection of Beam reinforcement The detailing of reinforcements and other required dimensions of the beams and steel cages are shown in Figure 1.

\begin{tabular}{|l|l|l|}
\hline $\begin{array}{l}\text { \% steel } \\
\text { provided }\end{array}$ & $\begin{array}{l}\text { Astprovided } \\
\mathbf{2}\end{array}$ & $\begin{array}{l}\text { Reinforcement } \\
\text { details }\end{array}$ \\
\hline 0.84 & 100.53 & $\begin{array}{l}\text { 8 dia-2 nos } \\
\text { Hanger bar:8 dia-2 } \\
\text { nos Stirrups:2L- } \\
\text { 8dia@90mm c/c }\end{array}$ \\
\hline 1.31 & 157.08 & $\begin{array}{l}\text { 10 dia-2 nos } \\
\text { Hanger bar:8 dia-2 } \\
\text { nos Stirrups:2L- } \\
\text { 8dia@90mm c/c }\end{array}$ \\
\hline 1.88 & 226.19 & $\begin{array}{l}12 \text { dia-2 nos } \\
\text { Hanger bar:8 dia-2 } \\
\text { nos Stirrups:2L- } \\
\text { 8dia@90mm c/c }\end{array}$ \\
\hline & &
\end{tabular}

Figure 1: Details of the Beam Dimensions and Reinforcement Cages
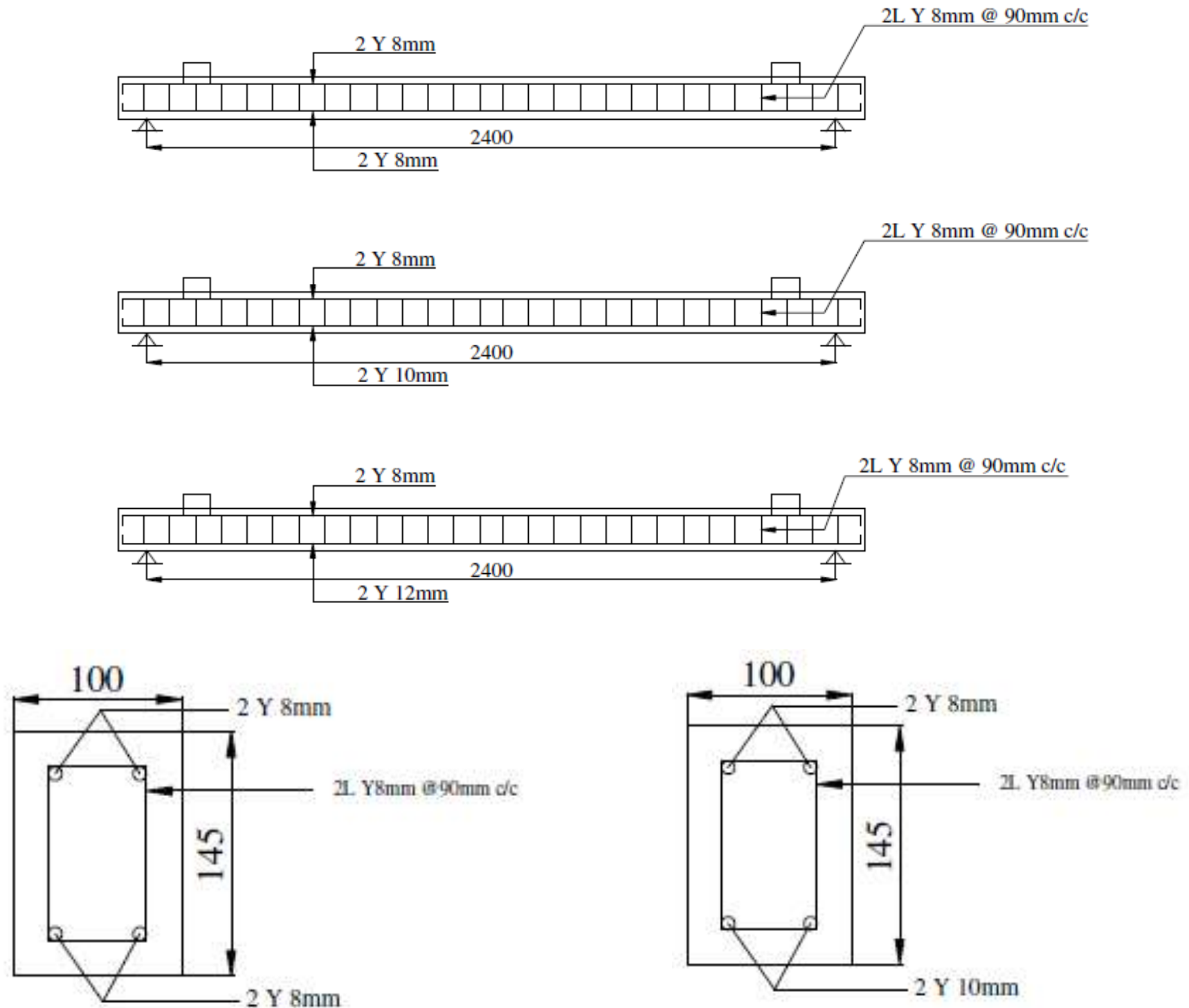


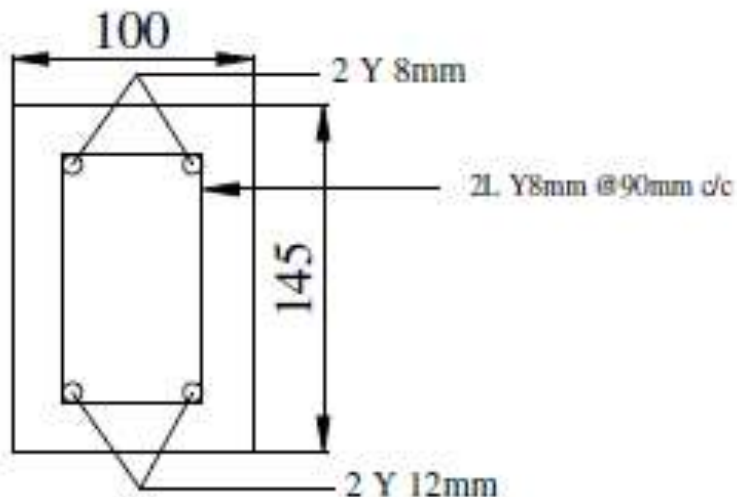

\section{RESULTS AND DISCUSSION}

\subsection{Compressive Strength \& Flexural Strength}

A number of trail mixes were conducted to obtain the mix proportion of M40 concrete. Compressive strength of the concrete influences the flexural behaviour of concrete beams. Therefore for each set of the beam specimen three cubes of $100 \times 100 \times 100$ and three prisms of $75 \times 75 \times 450$ were casted and tested. The results are tabulated in Table 6.the variation of compressive strength over the age (days) is presented in Figure 2.

Table 6: Flexural strength of Cinder Aggregate Concrete.

\begin{tabular}{|l|l|l|l|}
\hline Beam & b mm & $\mathbf{d ~ m m}$ & $\begin{array}{l}\text { Flexural Strength } \\
\text { (MPa) }\end{array}$ \\
\hline $\mathrm{N}-0-1$ & 100 & 120 & 5.61 \\
\hline $\mathrm{N}-0-2$ & 100 & 120 & 4.81 \\
\hline $\mathrm{N}-0-3$ & 100 & 120 & 5.61 \\
\hline $\mathrm{N}-30-1$ & 100 & 120 & 4.67 \\
\hline $\mathrm{N}-30-2$ & 100 & 120 & 5.45 \\
\hline $\mathrm{N}-30-3$ & 100 & 120 & 5.45 \\
\hline $\mathrm{N}-50-1$ & 100 & 120 & 6.09 \\
\hline $\mathrm{N}-50-2$ & 100 & 120 & 4.57 \\
\hline $\mathrm{N}-50-3$ & 100 & 120 & 5.33 \\
\hline $\mathrm{N}-75-1$ & 100 & 120 & 5.38 \\
\hline $\mathrm{N}-75-2$ & 100 & 120 & 4.61 \\
\hline $\mathrm{N}-75-3$ & 100 & 120 & 6.15 \\
\hline
\end{tabular}

It has been observed from the graph that the 1day strength for $50 \%$ replacement of CA was higher compared to $0,30 \&$ $75 \%$. There is not much variation in the 3 and 7 day compressive strength. $0 \%$ replacement shows highest compressive strength followed by 30,50 and $75 \%$. It can also been observed that the mix with $50 \%$ replacement of CA reached the target compressive strength earlier followed by 0,75 and $30 \%$ subsequently.

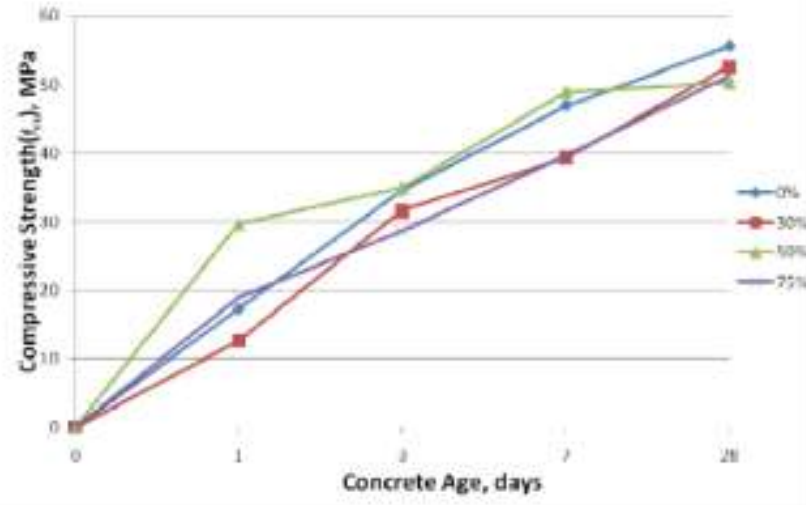

Figure 2: Age v/s Compressive strength curve for different replacements of coarse aggregate.

\subsection{Combined Load V/S Deflection Curve}

Combined load deflection behaviour based on the percentage replacement of cinder for various percentages of tensile reinforcement is presented below.

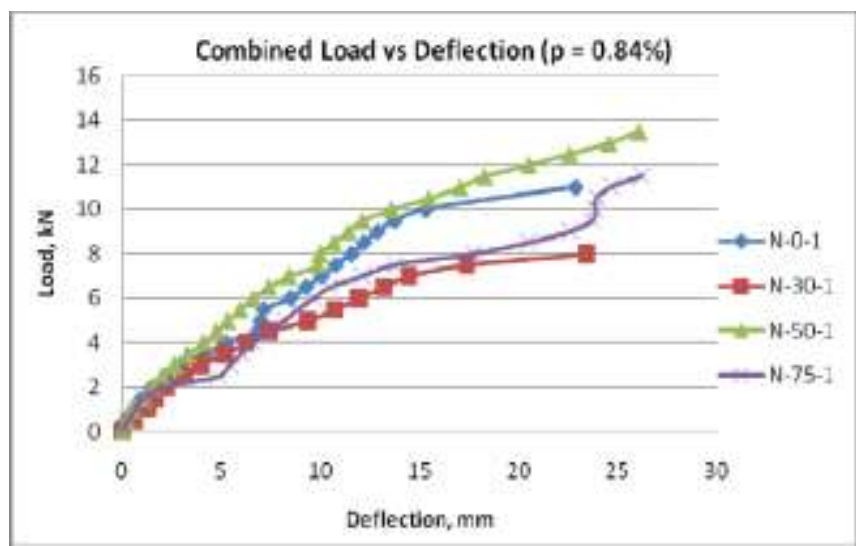

Figure 3: Combined Load v/s Deflection curve for $\mathrm{p}=$ $0.84 \%$

The graph indicates that the load as well as the deflection is higher for beam with $50 \%$ replacement of coarse aggregate. The ultimate load of Beam N-30-1is the least compared to all the other percentages ofreplacement.

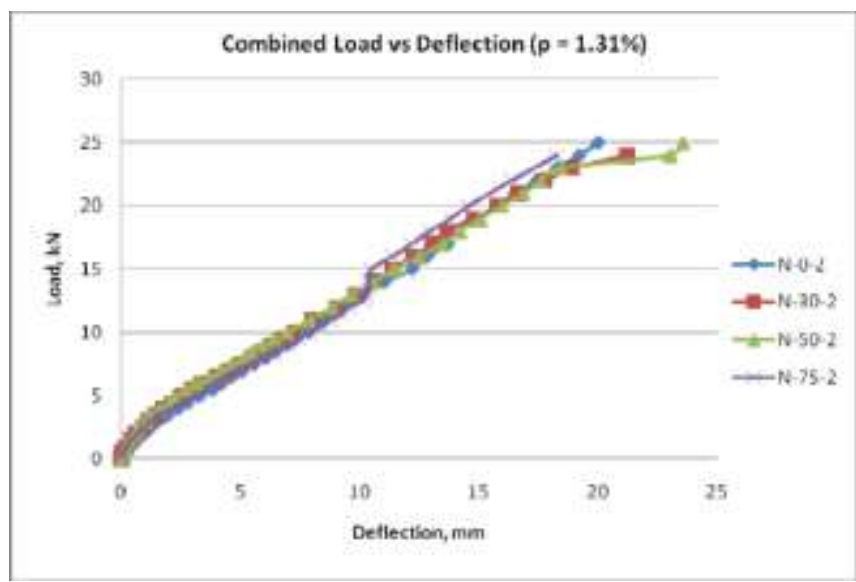

Figure 4: Combined Load v/s Deflection curve for $\mathrm{p}=$ $1.31 \%$ 
All the beams show linear variation towards the ultimate capacity. The variation in the deflection and load carrying capacity is very small in all the beams. But, in case of $\mathrm{N}$ $75-2$, at around $13 \mathrm{kN}$, there was a very small increase in deflection with the increase in load up to $15 \mathrm{kN}$, thereafter, the load v/s deflection curve shows same trend as other beams. The ultimate loads of all the beams are almost the same whereas the deflections very much, with beam N-50-2 having more deflection compared to others.

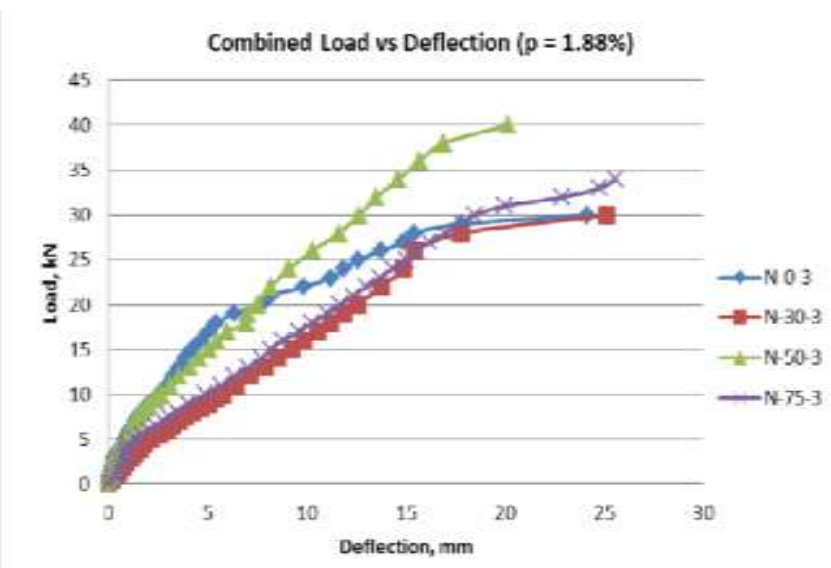

Figure 4.17: Combined Load v/s Deflection curve for $\mathrm{p}=$ $1.88 \%$

There is a considerable difference in the deflection and load carrying capacity of beam N-50-3 compared over the other three beams. The load deflection curve for $\mathrm{N}-0-3$ is steeper up to $20 \mathrm{kN}$. The load deflection curves for N-30-3 and N75-3 follow the same trend.

\subsection{Cracking And Ultimate Load}

The cracking and ultimate load along with the maximum deflection and crack width were recorded during the testing of each beam and the same is reported in the Table 7.

Table 7: Cracking and Ultimate load of beams.

\begin{tabular}{|l|l|l|l|}
\hline Beam & $\begin{array}{l}\text { Pu } \\
\text { kN }\end{array}$ & $\begin{array}{l}\text { Crack width } \\
\mathbf{m m}\end{array}$ & $\begin{array}{l}\Delta \mathbf{m a x} \\
\mathbf{m m}\end{array}$ \\
\hline $\mathrm{N}-0-1$ & 11 & 0.04 & 22.86 \\
\hline $\mathrm{N}-0-2$ & 25 & 0.15 & 20.01 \\
\hline $\mathrm{N}-0-3$ & 30 & 0.08 & 24.12 \\
\hline $\mathrm{N}-30-1$ & 8 & 0.07 & 23.43 \\
\hline $\mathrm{N}-30-2$ & 24 & 0.07 & 21.25 \\
\hline $\mathrm{N}-30-3$ & 30 & 0.12 & 25.12 \\
\hline $\mathrm{N}-50-1$ & 13.5 & 0.05 & 26.07 \\
\hline $\mathrm{N}-50-2$ & 25 & 0.15 & 23.57 \\
\hline $\mathrm{N}-50-3$ & 40 & 0.04 & 20.13 \\
\hline $\mathrm{N}-75-1$ & 11.5 & 0.12 & 27.71 \\
\hline $\mathrm{N}-75-2$ & 24 & 0.1 & 18.29 \\
\hline $\mathrm{N}-75-3$ & 34 & 0.05 & 25.57 \\
\hline
\end{tabular}

It has been observed from the abovethat with the increase in percentage of tensile reinforcement, the ultimate load capacity increased. It is also evident that with the increase in tensile reinforcement ratio, there is an increase in the cracking load.

Table 8: Deflection of beams at various load levels

\begin{tabular}{|c|c|c|c|}
\hline Beam No. & $\begin{array}{c}\mathbf{w} \\
(\mathbf{m m})\end{array}$ & $\begin{array}{c}\text { Failure } \\
\text { Load Pu } \\
(\mathbf{k N})\end{array}$ & $\begin{array}{c}\mathbf{u} \\
(\mathbf{m m})\end{array}$ \\
\hline N-0-1 & 10.28 & 11 & 22.86 \\
\hline N-0-2 & 13.14 & 25 & 20.01 \\
\hline N-0-3 & 7.69 & 30 & 24.12 \\
\hline N-30-1 & 9.52 & 8 & 23.42 \\
\hline N-30-2 & 12.21 & 24 & 21.25 \\
\hline N-30-3 & 12.34 & 30 & 25.12 \\
\hline N-50-1 & 11.62 & 13.5 & 26.07 \\
\hline N-50-2 & 12.62 & 25 & 23.56 \\
\hline N-50-3 & 10.47 & 40 & 20.13 \\
\hline N-75-1 & 15.01 & 11.5 & 27.71 \\
\hline N-75-2 & 12.10 & 24 & 18.29 \\
\hline N-75-3 & 13.18 & 34 & 25.57 \\
\hline
\end{tabular}

Table 9: Deflection of beams at working load using different codes

\begin{tabular}{|c|c|c|c|}
\hline $\begin{array}{c}\text { Beam } \\
\text { no. }\end{array}$ & $\begin{array}{c}\text { ACI 318- } \\
\mathbf{2 0 1 0} \\
\mathbf{m m}\end{array}$ & $\begin{array}{c}\text { IS 456 } \\
(\mathbf{m m})\end{array}$ & $\begin{array}{c}\text { Experimental } \\
\text { Deflection } \\
(\mathbf{m m})\end{array}$ \\
\hline $\mathrm{N}-0-1$ & 8.70 & 7.44 & 10.28 \\
\hline $\mathrm{N}-0-2$ & 15.11 & 15.45 & 13.14 \\
\hline $\mathrm{N}-0-3$ & 13.94 & 14.54 & 7.69 \\
\hline $\mathrm{N}-30-1$ & 5.80 & 4.36 & 9.52 \\
\hline $\mathrm{N}-30-2$ & 14.65 & 14.98 & 12.21 \\
\hline $\mathrm{N}-30-3$ & 14.24 & 14.95 & 12.34 \\
\hline $\mathrm{N}-50-1$ & 11.24 & 10.37 & 11.62 \\
\hline $\mathrm{N}-50-2$ & 15.60 & 16.17 & 12.62 \\
\hline $\mathrm{N}-50-3$ & 18.49 & 19.70 & 10.47 \\
\hline $\mathrm{N}-75-1$ & 9.16 & 7.94 & 15.01 \\
\hline $\mathrm{N}-75-2$ & 14.42 & 14.64 & 12.10 \\
\hline $\mathrm{N}-75-3$ & 16.64 & 17.75 & 13.18 \\
\hline
\end{tabular}

\section{CONCLUSION}

The report presents information on Normal strength concrete with cinder aggregates. Cinder is used to replace natural aggregates in varying percentage. Various trial mixes were done to obtain M40 grade concrete. A total of twelve beams were cast with varying percentage of reinforcement and varying percentage of coarse aggregate replacement. The 
deflection of the beams at working and ultimate loads is noted and the value is also calculated using various codes. The experimental deflection was found to be higher than the deflection calculated using all the other codes in case of beams with lowest percentage of tensile reinforcement $(\rho=$ $0.84 \%)$. The experimental deflections of the remaining beams with higher percentages of tensile reinforcement $(\rho=$ $1.31 \% \& \rho=1.88 \%$ ) were lower than the calculated values. And it was observed that, the experimental deflections of beams with highest percentage of tensile reinforcement $(\rho$ $=1.88 \%$ ) was found to be less and varied too much compared to the calculated values. It is found that ACI code gives the best mean of 0.97 and has the least coefficient of variation of 0.37 . It was observed for beams with $\rho=0.84 \%$, that the variation in the load values of beams was less for a deflection value of $\mathrm{L} / 750(\Delta=3.2 \mathrm{~mm})$. For a deflection value of $\mathrm{L} / 500(\Delta=4.8 \mathrm{~mm})$, beam N-50-1 had higher load compared to other beams. It was observed for beams with $\rho$ $=1.31 \%$, that the variation in load values with the increase in deflection was less for all the beams. Except for beam N75-2, the same trend was followed by all the beams until the ultimate capacities of the beams were reached. It was observed that beams with $\rho=1.88 \%$ and with $30 \%$ and $75 \%$ replacement of CA followed the same trend until the failure and the variation in the load and deflection values is less. The beams with $0 \%$ and $50 \%$ replacement of CA had same trend of variation in load with increase in deflection up to a value of deflection between L/500 and L/250, after which the beam N-50-3 had higher load capacity with increase in deflection.

\section{REFERENCES}

[1]. Muyasser M Jomaa'h, Hosam A Daham, Saad M Rao, "Flexural Behavior of Lightweight Concrete Beams" European Journal of Scientific Research ISSN 1450216X Vol.58 No.4 (2011), pp.582-592

[2]. P.Turgut and E. S.Yahlizade (2009), "Research into Concrete Blocks with Waste Glass", International Journal of Civil and Environmental Engineering 1:42009.

[3]. N Siva LingaRao, G VenkataRamana, V Bhaskar Desai \& B L P Swamy "Properties of Light Weight Aggregate Concrete with Cinder and Silicafume Admixture" International Journal of Earth Sciences and Engineering ISSN 0974-5904, Volume 04, No 06 SPL, October 2011, pp907-912

[4]. Michelle Danko, Edgar Cano and Jose Pena, "Use of Recycled Tires as Partial replacement of Coarse Aggregate in the Production of Concrete" Purdue University Calumet,2006.

[5]. Bureau of Indian Standards "Plain and Reinforced Concrete Code of Practice", IS 456:2000.

[6]. American Concrete Institute "Building Code Requirements for Structural Concrete and Commentary", ACI318-02,2010. 